\title{
The local integration of employment services: assessing network effectiveness of local job centres in Flanders
}

\author{
Ludo Struyven, Line Van Hemel \\ Higher Institute of Labour Studies, Catholic University Leuven, Parkstraat 47, PO Box 5300, \\ 3000 Leuven, Belgium; e-mail: ludo.struyven@hiva.kuleuven.be, \\ line.vanhemel@hiva.kuleuven.be \\ Received 19 May 2008; in revised form 22 December 2008; published online 26 May 2009
}

\begin{abstract}
In the Flemish region of Belgium, as in many other countries, the network paradigm is the emerging model for the establishment of local job centres. Based on a one-stop service model, similar basic work-focused services which were previously offered by separate organisations are now integrated and locally embedded. What is the added value of the local establishment of public service delivery based on the network paradigm? This question is answered by using a set of evaluation criteria which we derive from Provan and Milward's framework for evaluating the effectiveness of local, public service networks for health care and welfare. The objective of this research is twofold: (a) a methodological assessment of Provan and Milward's framework; and (b) the empirical evaluation of job centres' effectiveness. Our empirical analysis is based on a mixed method approach, combining registration and organisational data analyses with qualitative findings as reported by stakeholders. We conclude that the network effectiveness of the job centres in Flanders for the year 2006 is not unanimously positive.
\end{abstract}

\section{Introduction}

One of the major components in the shift towards activation is the establishment of local job centres. The actual design of the 'single gateway' or 'one-stop' centres can differ among countries, depending on choices made concerning the target population, the cluster of related services, and the actors involved (Clasen et al, 2001). Despite these differences, one can observe two striking similarities. First, there is their local embeddedness, typically at the level of a single municipality or group of municipalities. Second, the organisation is based upon a new logic of governance through networks of government, nongovernmental organisations (NGOs), and other actors. In some countries the new mode of governance takes the form of a network organisation. This is currently the case in Belgium.

In this paper we deal with the network paradigm as the emerging model for the management and implementation structure of public service delivery (Considine, 2003; Henman and Fenger, 2006; Kickert et al, 1997). Criticism of existing services described them as insufficiently client oriented (Derksen et al, 1995). A number of trends in economy and society have made policy more complex than ever before and create growing interdependence between actors on different levels (Bogason, 2000). As in many other policy domains, the labour market policy field became densely populated by partnership and collaboration structures. In addition, the premise among policy actors was that uncoordinated actions by individual organisations are inadequate to enhance long-term employability. Attention was increasingly turned towards the local level, based on the belief that local partnerships are better able to respond to local labour market issues (Considine, 2006; McQuaid et al, 2006). This assumption is supported by game theory but social scientists such as Provan and Milward (2001) make the objection that this cannot automatically be applied to the establishment of public services. Integrated cooperation does, after all, impose specific requirements on the 
participating organisations. Research into the effectiveness of the services offered by the network organisation should also take this into consideration.

In other words, the question is how the network organisation of public services makes a difference to the evaluation policy effectiveness. What is the added value of the establishment of public service delivery based on the network paradigm? This question is answered based on empirical research into the local job centres in the Flemish region of Belgium. Job centres are a recent Flemish version of the one-stop shops, as also found in other countries in the field of benefits and placement.

The starting point for this research is that, in contrast to mainstream econometric research into the labour market effects of placement services, in evaluating networkorganised services attention is required first and foremost for the effectiveness of the collaborative process. To this end we seek to tie in with the various researchers who have studied the effectiveness of local partnerships (Mandell et al, 2006; Provan and Milward, 1995; 2001). Provan and Milward use the concept of network effectiveness, which we can concisely restate as the impact of the partnership on the structure and operation of services and relevant partner organisations (2001, page 414).

The problem with evaluating network effectiveness is the dynamic nature of networks and the multiplicity of stakeholders involved in a network. Provan and Milward (2001) developed an analysis framework for evaluating the effectiveness of local, public service networks for health care and welfare. The authors distinguish three analysis levels at which network effectiveness can be evaluated: local community, local partnership, and local actors. In this paper we build further on this model and assess how this model can be used to evaluate the functioning of the partnership in the Flemish local job centres.

\section{The local job centres in the Flemish region of Belgium}

Most Western countries are involved in major organisational changes in the way services for the unemployed are delivered. Services for those who are dependent on unemployment benefits and services for inactive target groups, depending on other delivery organisations, are integrated into a one-stop service. One-stop services usually cover 'front office' functions such as registration of the job seeker, benefit payment, intake, direct placement on vacancies, or assignment on labour market programmes.

In Flanders the establishment of the local job centres in the year 2000 meant a transition to a policy paradigm in which interadministrative cooperation, local embedding, and transparency of services became the new guiding principles. To this end an interadministrative framework agreement (1999) was reached between the federal government, the Flemish government, and local authorities. The local job centres themselves were rooted in the Vlaamse Dienst voor Arbeidsbemiddeling en Beroepsopleiding (VDAB) decree (2004). The local job centres are founded on two pillars: integrated services and the development of a local service economy. For the first pillar-integrated services-job seekers, employers, and employees are the three client groups. VDAB, ${ }^{(1)}$ the main actor in the field of public employment services in Flanders, was appointed as director of integrated services, defined as the basic services of the VDAB, integrated with those of the other partners. One of the important principles of integrated services is the creation of one file per client: data about clients are gathered by all partners using one single computer system, the VDAB Client Monitoring System.

(1) The VDAB (Flemish public employment service) is the public player on the Flemish labour market. It has the status of an externally autonomous government agency, and is run jointly by the Flemish social partners. 
In contrast to other countries the Flemish local job centres are not explicitly meant to integrate benefit and placement services into a single service. From an international perspective the integration of services concerns two different elements: the integration of benefits and placement services, and the integration of job seekers depending on unemployment benefits and job seekers depending on other benefits (incapacity-related benefits, social allowances) (Clasen et al, 2001; Karagiannaki, 2007). Only the latter has taken place in Flanders, and only for the 'active' component of services aimed at bringing unemployed people back to work. The national benefits agency, Rijksdienst voor Arbeidsvoorziening (RVA) in Belgium is not formally involved into the local job centres, although it was not prohibited. After the state reform of 1988, unemployment insurance schemes became the responsibility of the federal social security institution RVA, while responsibility for job brokerage and reintegration of job seekers was based mainly in the hands of the Flemish government and the VDAB. This typical split within federal countries like Belgium makes integration at the local level all the more complex. What is similar to all types of integrated job centre is their local dimension. This has also been the case in Flanders (figure 1). The partners for the integrated services are local organisations. At the municipalities' side of it are the local social office (known as OCMW ${ }^{(2)}$ ) and the local employment agency (known as PWA ${ }^{(3)}$ ). Both are organised in each of the 308 municipalities in Flanders. The local social offices come under the local authorities while the local employment agencies come under the federal benefits agency, and are controlled by the local authorities. The local social office is responsible for the payment of subsistence wage and job-seeking activities of social assistance clients, while the local employment agency provides temporary work experience for the very long-term unemployed while they remain on unemployment benefits (the so-called 'PWA work'). Other local partners are the job-seeking services for the disabled (since 2006 integrated into the VDAB). ${ }^{(4)}$

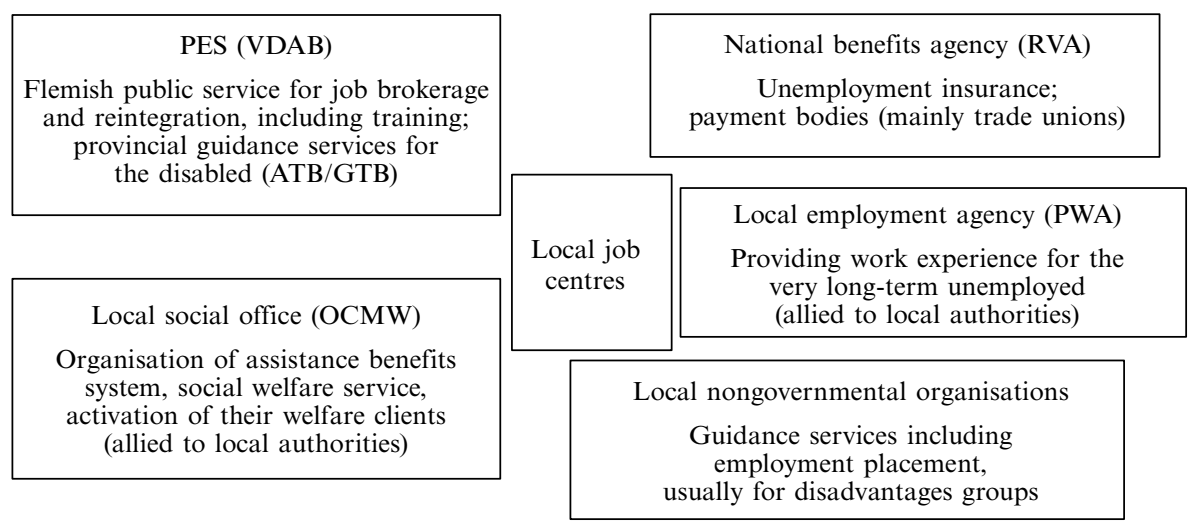

Notes: PES = Public Employment Service; VDAB = Vlaamse Dienst voor Arbeidsbemiddeling en Beroepsopleiding; ATB $/$ GTB = Arbeids TrajectBegeleiding/Gespecialiseerde TrajectBegeleiding; OCMW = Openbaar Centrum voor Maatschappelijk Welzijn; RVA = Rijksdienst voor Arbeidsvoopzieming; PWA = Plaatselijk Werkgelegenheidsagentschap.

Figure 1. Types of partner involved in the job centres.

(2) Openbaar Centrum voor Maatschappelijk Welzijn (public social welfare centre). These centres are allied to the local authorities, responsible for the organisation and activation of their welfare clients through the national assistance benefits system.

(3) Plaatselijk Werkgelegenheidsagentschap (local employment agency). These services are equally allied to the local authorities, and serve as a local branch of the national benefits agency, RVA.

(4) ATB/GTB: Arbeids TrajectBegeleiding/Gespecialiseerde TrajectBegeleiding (trajectory guidance for the disabled). 
These services are established at a provincial scale. Finally, there are, depending on the local situation, local NGOs which are recognised in the field of employment placement and guidance, usually for disadvantaged groups.

Local authorities were appointed as directors for the development of the local service economy, the second pillar. The local service economy includes employment initiatives for personal or collective social services of a local nature, including cleaning help, community development work, and odd-job services. The local administrations are responsible for opening up information about the local range of services via the job centre and the digital database of service providers, a virtual 'counter' (called Dienstenwijzer). A local employment policy forum was set up for each area of operation, responsible for monitoring the job centres, advising on new initiatives in the second pillar and wider labour market policy. Since the second pillar was mainly a pilot project in thirteen city centres at the time the research was conducted, we will focus here on the first pillar, the integration of basic services. For both pillars table 1 summarises the main characteristics in the design of Flemish local job centres.

Right from the start the job centres were intended to be locally embedded. The lowthreshold nature of the services with respect to job seekers was regarded as a priority in this respect. Since the establishment of a job centre requires a minimum volume of job seekers, however, it was not possible to open a job centre in every municipality. For this reason a lower and upper limit were defined which had to contain the weighted number of target audience units (job seekers) for the establishment of a job centre. Every job centre therefore serves a geographically defined zone, a 'care area'. A care area can consist of several municipalities (intermunicipal care area), one single municipality (municipal care area), or a part of a city (intraurban care area). ${ }^{(5)}$ The Flemish government had a distribution plan drawn up which had to be locally ratified among

Table 1. Design characteristics of the current concept of local job centres in Flanders.

\begin{tabular}{|c|c|c|}
\hline & First pillar & Second pillar \\
\hline Type of service & integrated services & local services economy users \\
\hline Target groups & $\begin{array}{l}\text { unemployed job seekers } \\
\text { employers } \\
\text { employees }\end{array}$ & \\
\hline Director & $\begin{array}{l}\text { public employment service } \\
\text { (VDAB) }\end{array}$ & local authorities \\
\hline \multirow[t]{2}{*}{ Partners } & $\begin{array}{l}\text { VDAB }+ \text { services for disabled } \\
\text { (ATB/GTB })\end{array}$ & local authorities \\
\hline & $\begin{array}{l}\text { local social services (OCMW) } \\
\text { local employment agency } \\
\text { (PWA) } \\
\text { nonprofit organisations }\end{array}$ & PWA service company \\
\hline $\begin{array}{l}\text { Total number operating } \\
\quad \text { in } 2006\end{array}$ & 134 & $\begin{array}{l}\text { mainly in the thirteen larger } \\
\text { cities }\end{array}$ \\
\hline Number planned & 141 & \\
\hline
\end{tabular}

Number planned

Notes: $\mathrm{VDAB}=$ Vlaamse Dienst voor Arbeidsbemiddeling en Beroepsopleiding; ATB $/$ GTB $=$ Arbeids TrajectBegeleiding/Gespecialiseerde TrajectBegeleiding; OCMW = Openbaar Centrum voor Maatschappelijk Welzijn; PWA = Plaatselijk Werkgelegenheidsagentschap.

(5) In 2006 most of the care areas are of the intermunicipal type, whether they are organised in one local job centre or in several local job centres (several municipalities = one care area $=$ one or several job centres). Only 21 of the 121 care areas are municipal (one municipality = one care area $=$ one job centre), while 17 care areas cover a part of a larger city (one city $=$ several care areas $=$ several job centres). 
the partners through a local cooperation agreement. In other words, local deviations from the plan were possible. The establishment of 141 job centres was envisaged, spread among 308 Flemish municipalities. In 2006, five years after the establishment of the first job centre, 134 job centres are operational.

\section{The multistakeholder perspective of effectiveness}

For Provan and Milward (2001) effectiveness acquires a broad definition - that is, broader than effectiveness for the labour market. In fact, they include under 'effectiveness' all criteria which indicate whether and to what extent a network 'functions well'. An important part of the effectiveness of networks (distinct from the effectiveness of labour market tools such as job matching or trajectory guidance) is consequently to be found in what we can call institutional effectiveness, or the impact on the structure and operation of services and organisations involved in the partnership. Research into the institutional effectiveness is important in itself. It is possible that a link may exist between the design and implementation of services and the labour market impact of the overall labour market tools, but the effect on job entry outcomes remains out of scope of this research. Examples of institutional impact are when organisations take into consideration the existence of the job centre for their other activities outside the job centre, when collaboration in the job centre increases to include more tasks than initially started, and when collaboration in the job centre leads to collaboration in other fields. The analysis framework must devote sufficient attention to this institutional effectiveness when evaluating the added value of the job centre.

The examples given here are each situated at a different analysis level. In the first example we are dealing with the consequences of the network for what the participating organisation itself performs in terms of activities; the second example concerns the consequences for what is produced by the partnership; and the third the consequences for the broader labour market operation. This three-way division corresponds to the three levels in the framework of Provan and Milward: 'organisation/participant', 'network', and 'community'. Every level implies a specific set of criteria for network effectiveness. These three levels are also applicable to the job centres, where community stands for the local community, network for the local partnership, and participant for the local actor.

Certain actors correspond to each level of analysis. The multiplicity of actors or stakeholders involved is typical of a network. This is what makes the evaluation of a partnership a complex affair-according to Provan and Milward, more complex than the evaluation of individual organisations. The job centre is a good illustration of such complexity because a multiplication of stakeholders arises when partner organisations are present.

It is customary to take the needs and expectations of the client as a starting point for the effectiveness of service organisations. This approach has become public property, although it is not entirely without problems: client needs can be fragmented and, consequently, lead to diverging visions among client-stakeholders. Moreover, the job centre has various clients: job seekers as well as employers, employees, and users of the local service economy. Clients are an important stakeholder, but not the only one. This is even more true when different organisations collaborate to provide a public service. Authorities often invest resources in the network, which means that they take centre stage as an important stakeholder. Along the lines of Provan and Milward (2001) we therefore perceive the evaluation of the job centres from a multistakeholder perspective. Inspired by the agency theory of Jensen and Meckling (1976), in their model they identify three layers of stakeholder: 'principals', 'agents', and 'clients'. 
Applied to the situation of the job centre, various stakeholders can be identified: the Flemish government, the federal government, the VDAB, the national employment service (RVA), the local administration, the social partner organisation, job seekers, employers, employees, specific groups such as disadvantaged groups, subsistence wage clients, users of local employment services, etc. Some function as principal on one level and as agent at another level. The VDAB, for example, functions both as agent with regard to the Flemish government and as principal or director with respect to the job centre.

In this contribution we use the framework by Provan and Milward (table 2) as a starting point, where the criteria will be selected, adapted, and finalised in each case based on the job centres. At the level of the local community, authorities and clients are the most important stakeholders, as 'principals' and 'clients', respectively. At the level of the local partnership, the directors act as principals with regard to the other network partners, who function as agents with respect to the network. Other local actors, such as employers' federations, can feel a direct influence from the partnership. At the level of the local actors, the stakeholders are the managements of organisations, leaders within organisations, and the clients who are served by the relevant local actors.

The framework of Provan and Milward lends itself well to a policy area such as the labour market. After all, this area involves a large number of actors: not only job seekers and employers, but intermediary actors as well. The distinction of various stakeholders from public labour market services is therefore an approach which does justice to the complexity of this policy area. At the same time, however, the framework conceals a weakness. The identification of network effects at various levels from the stakeholder perspective conceals the fact that effects are contingent upon the structural context in which the constellation of mutual relationships between actors takes shape and evolves. Provan and Milward do indeed mention the structure within the contours of the network organisation but they pay no further attention to the broader, supraorganisational context within which the network functions. Their approach is therefore - in terms of Pawson and Tilley (1997) - partly unrealistic, because it is stripped of contextual factors in which intervention seems to work. This is a result of the underlying principal-agent starting point in their approach. Unlike Provan and Milward, we therefore propose a contextualised approach in this paper for analysing network effectiveness. Choices of stakeholders, in our conception, are limited by the context in which they are situated. Two dimensions seem important to use when

Table 2. Analysis model for the network effectiveness of the job centres (source: based on Provan and Milward, 2001).

Level Stakeholders Dimension

Local community Authorities, clients

Local partnership Directors, partners, other local actors
Management of organisations, responsible person within organisations, and individual clients

\section{Client reach}

Contribution to solving local labour market problems and innovation

Composition of partnership

Joint organisation of services

Strength and dynamics of partnership

Steering of the network

Perceived benefits with regard to legitimacy, resources, costs, and client results 
involving the context variable: the spatial dimension and the multilevel steering of public services or vertical governance. Both dimensions refer to the primary forms of horizontal and vertical governance. Firstly, the spatial context is particularly important for physical one-stop-shop services, close to the citizen and embedded in local society. It is expected that the establishment of one-stop-shop services in a major urban context will impose different requirements than in a small-scale urban context in which one municipality fulfils a clear central function for the surrounding municipalities. Furthermore, functioning also depends on the local presence of intermediary actors and their preexisting collaboration. The spatial variable here stands for a proxy variable for the local environmental context in the broad sense of the word and includes both the context of the local labour market and the local institutional context. A second dimension relates to the multilevel context of policy and organisation. Certainly, in a field such as the labour market, one exclusive responsible policy level is never present-rather, an interplay exists between various policy levels. This is certainly the case within the Flemish policy context. Firstly, the Flemish government acts as an interim level between European and federal levels on the one hand and the local level on the other hand; secondly, the Flemish government acts as hierarchic superior through the autonomous government agency of the VDAB with regard to the local partnerships with local administrations (Struyven and Verhoest, 2005). Below, we examine how both contextual factors influence the network organisation and its functioning.

\section{Results}

In this section we answer the question about the functioning of the job centres as a network organisation at local level. The findings are presented according to the three dimensions identified by Provan and Milward and the effectiveness criteria that can be distinguished at each level for the establishment of public employment placement services. Furthermore, we focus on the spatial and multilevel contexts which limit the possibilities for the stakeholders within the network. Five questions are central to our research. The first two questions deal with the impact on clients and local capital (which factors positively influence client reach and how does it generate local social capital to bring about innovation?) The third and fourth questions concern the impact of local job centres on the composition of partnerships (are all relevant partners involved?) and the services offered by this partnership (how far have basic services been integrated?). Finally, a fifth question deals with the perceived benefits by each of the partners.

In order to do justice to the dynamic nature of partnerships, process evaluation was chosen as a research method. Process evaluation is based on a mixed method approach and allows insight to be obtained into the way in which an action is undertaken in practice and the sticking points which can cause the action to fail (Swanborn, 1999). The network effectiveness criteria are examined-both quantitative, through data analysis on client registration files, and qualitative, through reported effects by those involved. Firstly, relevant documents were collected regarding the setup of the job centres and the organisation of various actors involved. Then available administrative data were gathered concerning the use of the services, the spatial distribution of the job centres, staff numbers, and the composition of the partnership. Finally, forty-five semistructured interviews were conducted in eight local job centres, selected on the basis of variation in the age of the partnership, the unemployment rate in the care area, the province, and the degree of urbanisation. In addition, supralocal interviews were held with four central actors. ${ }^{(6)}$

(6) VDAB, local job centres project cell at central level, trajectory guidance for the disabled, and the local networks centre as representative of local NGOs or third parties. 


\subsection{Level of the local community}

At the level of the local community, clients and governments are the most important stakeholders. Three criteria play a role here: the extent to which the network contributes to an improvement in services provided, to reducing or resolving local labour market problems, and the innovation dividend of the local partnership.

\subsubsection{Impact on clients}

Provan and Milward (2001) offer the client reach as an indicator of the effectiveness of a network. The question arising here is which job centre characteristics can contribute to the client reach (research question 1). It can be expected that the number of partners and the number of staff members they post will positively influence the client reach (Koning, 2007). After all, greater staff commitment does increase the uptake capacity of a job centre. A second hypothesis is that, alongside the job centre characteristics, the spatial context-broadly summarised here as the local labour market and geographic characteristics - influences the client reach. Two spatial variables are particularly relevant in this respect: the degree of urbanisation and the distance from the job centre. It is expected that larger cities have more difficulties in reaching clients than average and that client reach is higher for those job seekers who live in the municipality where the job centre is located - this is called municipal presence. Besides the partnership characteristics and spatial variables, characteristics of the job-seeker population are a third category of variables which can influence the client reach of job centres. It is expected that, in line with the digital divide, the highly educated job seekers may be registered relatively more electronically, without the help of a physical counter.

In order to test these hypotheses, use was made of administrative data concerning the client reach of the job centre, specifically registration as a job seeker. Registration as a job seeker is an essential component of the basic services and a condition for receipt of an unemployment benefit. Registration can take place in one of four ways: a consultant, the self-service machines in a VDAB branch or job centre, the Internet, or the VDAB call centre. ${ }^{(7)}$ The client reach, operationalised as the percentage of registrations taking place in the job centre, was calculated for each job centre (or per care area). The global client reach of the job centres is $69 \%$, which can be termed considerable. The reach does fluctuate significantly among the job centres. The minimum and maximum values are $9 \%$ and $88 \%$, respectively. The registration data were complemented by administrative data for job centres and for the job-seeking population. Our testing is based on a multiple linear regression analysis following a pooled ordinary least squares model. Regression analysis is used to examine the influence of partnership characteristics (number of partners, percentage of staff who have a fixed workplace at the job centre), characteristics of the job-seeking population (presence of underprivileged groups, level of education), and geographic characteristics (degree of urbanisation, municipal presence) on the client reach, as shown in table 3. One outlier with a level of client reach below $10 \%$ was left out of the model. Variables were carefully selected to avoid multicollinearity. Three variables with a significance level of 0.10 were found. The model was regarded as significant $(F$-value $=10.29 ; p$-value $<0.0001)$ and explains $43 \%$ of the variance, which can be termed considerable.

Not one variable relating to the partnership was retained in the model. This means that the composition of the partnership and the staff employed in the job centre have no direct influence on use. An explanation is that registration as a job seeker in most

(7) Based on all registration data for 2005 , the division between channels was as follows: $52.6 \%$ of all registrations were managed by a consultant, $23.3 \%$ of the registration has been dealt with using self-service machines, $19.9 \%$ were registered through the Internet, and $4.2 \%$ through the VDAB call centre. 
Table 3. Regression model (ordinary least squares) for the variable client reach at job centre level $(N=122)$, based on all registration data for $2005(N=378307)$.

Standardised
coefficient

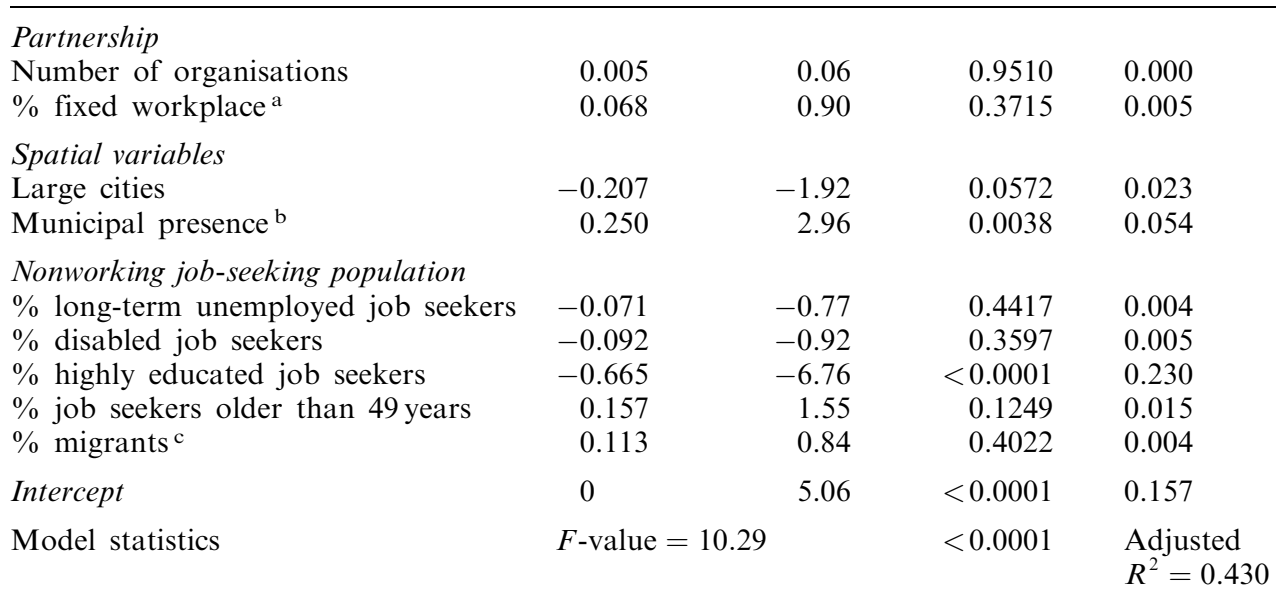

${ }^{a}$ Percentage of the staff who have a fixed workplace at the job centre.

${ }^{b}$ Nonworking job seekers in the care area living in the municipality where the job centre is located.

${ }^{\mathrm{c}}$ Percentage of nonworking job seekers of non-European nationality.

job centres is only carried out by the VDAB. After all, of the staff deployed for intake and basic services, $92 \%$ are posted by the VDAB. Only $1.37 \%$ of job seekers are registered by a partner consultant other than the VDAB.

As is to be expected, the level of education of the job-seeking population, a proxy for the job seekers' ability to cope, is the most important explanatory variable (partial $R^{2}=0.23$ ). The highly educated make more use of the Internet to register and are less likely to go to the job centre. This is a positive finding, since it means that the job centre reaches those most in need in the first instance. Other characteristics of the nonworking job-seeking population have not influence on the reach of clients.

Which spatial variables explain the client reach, in addition to personal variables? Job centres located in a large city or an intraurban care area (Antwerp and Ghent) have a lower client reach than other job centres. A specific metropolitan problem is posed in terms of channelling job seekers to the job centre. Finally, municipal presence, a proxy for the distance job seekers have to travel to the job centre, seems to be an important variable in explaining the reach. ${ }^{(8)}$ Job centres located in a large town (intraurban care area) or serving several municipalities (intermunicipal care area) therefore have a lower client reach than municipal care areas.

\subsubsection{Resolving local labour market problems and innovation (research question 2)}

A local partnership can be expected to make a contribution to resolving local labour market problems and to generate social capital by forging contacts with organisations in adjacent policy domains. However, operational cooperation in the job centre has so far been insufficiently placed within the context of a broader and more strategic approach to local and socioeconomic problems. For instance, the link with the local

(8) Approximately one quarter of the job-seeking population does not live in the municipal vicinity of a job centre (intermunicipal care area). 
social policy plan by the local social office is still missing. Among local authorities, the impetus to do something about broader labour market problems is erratic. Care areas with higher unemployment pressure are usually more dynamic than care areas with a lower unemployment pressure. This often has to do with greater problem perception, a longer tradition of collaboration, and the availability of experience, resources, and personnel.

Moreover, local partnerships are also assumed to be close to the citizen, which puts them in a better position to discover local niches and to launch innovative campaigns. In this way results of one initiative (job centre) can bring about an 'interaction effect' for local partnerships (Considine, 2003). Many campaigns have already been set in motion based on the job centre partnership. On the one hand, these actions focus on a more global approach to the match between demand and supply, including job fairs and breakfast sessions for employers about employment measures. On the other hand, these actions often focus on raising awareness about the job centre and channelling towards the job centre, in the form of leaflets and open days. Other policy initiatives are sometimes linked to the job centre, such as the youth unemployment plan. For example, in Antwerp a youth job centre was established. In Ghent, as part of this plan, job dating in the job centre was organised between employers, young people, and the relevant guidance counsellors.

\subsection{Level of the partnership}

At the level of the partnership four important criteria can be derived from Provan and Milward's framework for evaluating the functioning of a network: the composition of the partnership, the joint organisation of services, the strength and dynamics of the partnership, and the steering of the network. This level of analysis relates to the question of the impact on the partnership and on services offered (research questions 3 and 4) and is based on administrative data of 122 job centres, followed by interviews with staff in eight job centres.

As far as the composition of the partnership is concerned, a distinction is made between central and local partners (table 4).

At central level the core partner should be the benefits agency, RVA, which is responsible for organising unemployment insurance and partly for activating search behaviour. ${ }^{(9)}$ In practice, however, only minor involvement is observed since the RVA does not post personnel to the job centres. Furthermore, no place was envisaged for the payment institutions, responsible for paying out unemployment insurance, in the policy design of the job centres. ${ }^{(10)}$ The VDAB is the largest and most involved partner in the job centre, with a presence in $90 \%$ of job centres. Half of the job centre staff are seconded by the VDAB. The job centre therefore remains confined to a 'counter' for work, not for work and income, as is the case in other countries. The explanation for this can be found rather in the supralocal context. On the one hand, the division of the organisation and payment of unemployment insurance by the RVA and the various payment institutions (the social partners), respectively, lends itself less well to the organisation of this service into one single point. On the other hand, the division of unemployment insurance and employment placement between federal and Flemish powers, respectively, poses a political-constitutional obstacle to reintegration into a one-stop-shop service.

(9) At central administrative level automated alignment is in place between the regional VDAB and the federal RVA, so that a job seeker only has to register once as such. This alignment has nothing to do with the job centres.

${ }^{(10)}$ The main payment institutions are the trade unions. 
Table 4. Presence of organisations in 119 job centres, counting for 1311 staff members (2006).

Organisation

$\begin{array}{lll}\begin{array}{l}\text { Number of } \\ \text { job centres } \\ \text { present }^{\mathrm{a}}\end{array} & \begin{array}{l}\text { Percentage of } \\ \text { job centres } \\ \text { present }\end{array} & \begin{array}{l}\text { Percentage of } \\ \text { total staff }\end{array} \\ & \end{array}$

\section{Central bodies}

VDAB - public employment service

$\begin{array}{rll}106 & 89.08 & 50.50 \\ 77 & 64.71 & 8.77\end{array}$

RVA-national benefits agency ${ }^{b}$

payment bodies (trade unions) ${ }^{\mathrm{b}}$

Local bodies

PWA-local employment agency

OCMW - local social service

PWA - service company

Local authorities

Nonprofit organisations

Missing values

present

Total

$\begin{array}{rll}103 & 86.55 & 15.18 \\ 64 & 53.78 & 9.08 \\ 31 & 26.05 & 3.74 \\ 30 & 25.12 & 3.05 \\ 27 & 22.69 & 4.88 \\ & & 4.81 \\ 119 & 100.00 & 100.00\end{array}$

${ }^{a}$ Number of local job centres in which the organisation offers their services.

${ }^{b}$ Note that important partners at central/federal level are not presented in the current model of local job centres.

Notes: $\mathrm{VDAB}=$ Vlaamse Dienst voor Arbeidsbemiddeling en Beroepsopleiding; ATB / GTB $=$ Arbeids $\quad$ TrajectBegeleiding $/$ Gespecialiseerde TrajectBegeleiding; RVA $=$ Rijksdienst voor Arbeidsvoorziening; PWA = Plaatselijk Werkgelegenheidsagentschap; OCMW= Openbaar Centrum voor Maatschappelijk Welzijn.

At local level, employment services offered by local social offices to their social assistance clients as well as local employment agencies are envisaged. In practice, the local social office OCMW is only involved to a varying extent, specifically in half of the job centres. The OCMW participates as provider of specialised services (welfare-towork guidance) within the first pillar. When applying for social assistance benefits, subsistence wage clients cannot go to the job centre, but have to apply to the social department of the OCMW. The participation of the OCMW in the job centres is closely related to spatial variables. The OCMWs, municipally organised services just like the local employment agency (PWA), post staff to $90 \%$ of the job centres in a municipal care area. In the intermunicipal care areas the OCMW is only involved in half of the job centres and in the cities (intraurban care areas) the OCMW does not participate at all. In these latter two categories of care area the fields of operation of the OCMWs are incongruent with those of the job centres. The OCMWs are usually organised on a smaller scale. The choice of intermunicipal care areas is therefore not an obvious one, when the involvement of the OCMW and the PWA is assumed. After all, although the PWAs are the second largest partner, with a presence in $86 \%$ of job centres, this only applies to those PWAs located in the municipality where the job centre is situated.

A third category of local partners consists of trajectory guidance for the disabled and local NGOs. The trajectory guidance for the disabled, a provincially organised service, participates mainly in the urban care areas and less so in the rural care areas. ${ }^{(11)}$

(11) The rapid expansion of provincially organised ATB/GTB services means that the organisation infrastructure for the time is not in tune with the deconcentrated organisation of the local job centres. 
Local NGOs are mainly represented in the job centres located in the bigger cities. To summarise we can certain speak of colocation in terms of the organisation of services. As far as the one-stop-shop idea is concerned, this has in general been achieved at the level of intake, but the participation of local partners is very low in this case. ${ }^{(12)}$

In addition to the composition of the partnership, the services offered by this partnership represent a second effectiveness criterion at the level of the partnership. Those interviewed state that multiple problems affecting job seekers are often not detected by the basic services offered by the VDAB or the PWA. This usually happens by specialist provider, such as the ATB service and local NGOs, following a referral by them to VDAB or the PWA, depending on the uptake by these partners. As a rule this specialised screening takes place in the job centre, but the screening of subsistence wage clients, for example, is again performed by the social services of the OCMW. This finding leads to the more fundamental question of which services are and are not provided in the job centre.

Provan and Milward (2001) state that an effective network retains only the core partners over time, but also offers peripheral services, albeit with looser partnerships. For this reason we have made a distinction between primary help for job seekers and secondary guidance. This distinction sheds an illuminating light on the actual interweaving of guidance currently being offered in Flemish job centres. The job centre is conceived in the first instance in the policy document as a contact point for primary services, the integrated basic services. The universal services of the VDAB serve as the starting point for this. These universal services encompass all services and information which are provided free of charge by the VDAB, such as registering and accessing vacancies, registration as a job seeker, or information about training courses. By contrast, trajectory guidance for job seekers is individual and intensive in nature. For this reason we include this among the secondary services. It can therefore be expected that the job centre in the first instance includes those partners who provide primary services. In reality, both primary and secondary service tasks appear to be integrated into the job centre, albeit incompletely. This is shown in diagram form in table 5.

Table 5. Diagram of current services within and outside the job centre.

\begin{tabular}{ll}
\hline Primary services \\
\hline Basic services $^{\text {a }}$ & $\begin{array}{l}\text { PES (VDAB) } \\
\text { Local employment office (PWA, } \\
\text { indirectly linked to central } \\
\text { benefits agency, RVA) }\end{array}$
\end{tabular}

Trajectory guidance

Secondary services

PES (VDAB)

Local social office (OCMW)

Disabled (ATB/GTB)

Nongovernmental organisations

${ }^{a}$ Basic services do not include the payment of benefits, which in Belgium is mainly outsourced to the labour unions.

Notes: PES $=$ Public Employment Service; VDAB = Vlaamse Dienst voor Arbeidsbemiddeling en Beroepsopleiding; PWA = Plaatselijk Werkgelegenheidsagentschap; RVA = Rijksdienst voor Arbeidsvoorziening; OCMW = Openbaar Centrum voor Maatschappelijk Welzijn. ATB/ GTB $=$ Arbeids TrajectBegeleiding/Gespecialiseerde TrajectBegeleiding.

${ }^{(12)}$ Note that there are exceptions to this. One example is Ghent, where the various partners take turns providing support in the self-service area. 
The primary services of the benefits agencies (OCMW and RVA) do not take place in the job centre. The VDAB and, to a lesser extent, the PWA, refer clients on from the basic services to the trajectory guidance given by the job centre partners. The PWA, which received its tasks, personnel, and other resources from the RVA, also acts as a limited intermediary to the RVA for applying for simple certificates.

The trajectory guidance by the VDAB, OCMW, and NGOs is partially embedded in the job centre. Where secondary services are integrated into the job centre, this often leads to problems of domain demarcation and potential conflicts of interest, such as primarily referring on to one's own range of services. In principal, directing by the VDAB includes a built-in guarantee that channelling towards secondary services in the first instance is driven by the needs of the client (not by the range of services) but in practice this is not always adequately guaranteed or made transparent. Nonetheless, it can be said that integration at the level of the secondary service is greater than it is at the level of primary (intake and basic) services. This finding is striking, since the job centre was set up in the first instance to bring about integration at the level of basic services.

The strength and dynamics of the partnership are expressed in the number of ties between organisations (Provan and Milward, 2001). For instance, it seems that purely being together in one location represents an enormous improvement for informal contacts between organisations. The intensification of consultative forms such as the executive management and the channellers' consultative body contribute to the promotion of bilateral contacts between organisations. In addition, information technology (IT) plays an important role in connecting organisations. Access to the VDAB's wide range of tools is evaluated as an important benefit of the job centre. However, the partners often point to the cumbersome and extensive registration procedures which are extremely time-consuming and allow for little freedom in interpreting a trajectory or the guidance methodology. The Flemish government releases budgets for the job centres, but these only leave room for funding the infrastructure, not for setting up joint campaigns.

The fourth criterion concerns the steering of the network. At local level a branch manager was appointed for each job centre, who monitors the everyday running of the job centre. This function is assumed by the VDAB in at least $62 \%$ of the job centres. Those interviewed report that the powers of the branch manager are still too narrowly interpreted. In the first instance the branch manager is responsible for logistic steering on the centre floor. In some locations the VDAB is acquiring an unofficial function as job centre coach, based on the need for more strategic coordination of the network. This person acts as intermediary between the supralocal level of the VDAB and the local partners and focuses more on the content-related steering of the job centres. In the field the need for this function is usually recognised and accepted. Nonetheless, both the job centre coaches and the VDAB branch managers are sometimes accused of a lack of independence because they are overly controlled by supralocal interests of the VDAB.

\subsection{Level of the local actors}

At the level of the individual actors the question remains of how partners perceive the collaboration for the operation of their own organisations. This question on perceived benefits (research question 5) is answered on the basis of interviews with job centre staff.

According to Provan and Milward (2001) the benefits for smaller organisations from taking part on the network are greater than for large, established organisations. This does not correspond with what we found in our research on VDAB - local partnerships. 
Especially concerning the inflow of new clients, the perceived advantages are greater for VDAB than for local partners.

The effects of the services provided by those involved are the evolution towards one file per client, which means that duplicate counselling can be avoided-a more flexible transfer and matching within the context of recruitment for initiatives by partners, such as training in the building sector. In addition, steps are also being taken towards the release of a wide range of information. Sticking points are still being flagged in practice in this case. The link between the counters in the first and second pillars - in other words, channelling job seekers towards jobs in the local service economy - is very limited. Although the interdependence between organisations in both pillars is rising steeply, few internal links are being created. Information about the first pillar is not yet fully integrated into one counter, but is rather spread among the job centre and points partially beyond it. To some job seekers it is still not clear what they can obtain from the job centre. Services to employers and employees are virtually undeveloped.

The added value of the job centre for the VDAB is that it has attracted more attention to local problems and methods from other partners. However, one sticking point in this respect is that the strongly hierarchic steering at Flemish level interferes with the demand for local flexibility. In addition, other organisations make a substantial claim upon the VDAB in the resolution of problems concerning the specific implementation of services because of its directing role.

For the OCMW the job centre provides a flexible link between the subsistence wage and VDAB (or entitlement to benefits). However, in the field duplicate guidance often takes place by both partners because the OCMW is only erratically involved in the job centres. The primary service provided by the OCMW, applying for social assistance benefits, takes place exclusively in the local social office.

At the level of basic services the PWA plays an additional or duplicate role in this context with respect to the regular screening and activation of job seekers. The PWA holds intake interviews for its own target group of very long-term unemployed. These lead to a referral to a job in a service company, to PWA work, or to the secondary guidance services of the other partners. In some places the PWA also fulfils an informative role with regard to the second pillar, but at the same time acts as provider of services from the second pillar which is seen by other local actors as a distortion of competition. $^{(13)}$

For local NGOs participation in the job centre promotes access to VDAB channels, including the broad range of VDAB instruments (certificates, vacancies, training). However, the job centre does not as yet contribute to increasing intake into its own secondary guidance services. In the context of activation policies the VDAB is obliged to call all job seekers and to channel them into an offer of trajectory guidance, but no neutral channelling guarantee has yet been built in.

For the ATB/GTB the job centre means increased awareness and legitimacy, which leads to increased intake via the job centre partners. The embedding ATB/GTB services within the VDAB also leads to increased intake. The use of other partners as an interim link as a result of waiting times in their own organisations and networks is labelled by the ATB/GTB as an advantage of the job centre.

(13) One sticking point for the PWA work is that, despite the nature of its activities, it still has no place in the second pillar. Another sticking point is that rumours about the federal government's intention to abolish the PWAs make the other partners recalcitrant when it comes to channelling their clients into PWA work. 


\section{Conclusion and discussion}

The overall aim has been to identify and assess the development towards a single gateway by integrating basic services to job seekers at the local level in Flanders. As one of the major regions in Belgium, the case of Flanders highlights the structural barriers to the functional integration of narrowly related policy fields spread out in divided and sometimes overlapping competences at the federal (unemployment insurance), the regional (employment services), and the local level (social assistance). The starting point for our analysis is the shift to activation, pushing all relevant actors and policy levels to combine their efforts and share information in order to bring more workless people into paid work.

We hypothesised that the impact of a network organisation for job centre services on client reach will be positively influenced by three types of variables: partnership characteristics (composition and capacity of partners); spatial characteristics (municipal presence of a job centre), and job seeker population characteristics (disadvantaged groups). The analysis has shown that spatial and job seeker characteristics each count for significant differences in client reach, whereas partnership variables make no difference at all. Further in-depth analysis of the impact of the network organisation on partners and services has shown that, notwithstanding some positive findings, the predominance of the VDAB as main public employment service was decisive in taking up basic registration, intake, and referral tasks in the established job centres. This central role of the VDAB in the local job centres was even further reinforced. By sharing its IT system based on one file per client and taking the lead in the local coordination of a majority of job centres, VDAB has contributed to avoiding duplicate counselling and fostering a more flexible referral and matching of clients. But this central position has also a negative side, resulting in an only minor involvement of relevant agencies in basic services (federal and local agencies responsible for unemployment insurance clients and social assistance clients). On the contrary, secondary services of trajectory guidance were more easily integrated in the local job centre, but here we found a persistent tendency to refer to one's own range of services. This brings us to a twofold conclusion. First, one-stop job centres in Flanders have a positive impact on basic services for the unemployed with respect to registration as a job seeker, but at the same time do not succeed in establishing an integrated basic service with employment services offered by local actors. Second, as far as services provided by the partnership are concerned, the job centre does not offer integration of primary services and only partial integration of secondary services. The conclusion is that the job centre has evolved into a fragmented and incomplete mix of primary and secondary services.

Concerning the evaluation of network effectiveness, we have demonstrated that the analysis framework by Provan and Milward is a useful framework for evaluating local job centres. By evaluating their effectiveness in the light of three analysis levels - the local community, the partnership, and the local actors - a broad picture of the operation of the partnership is obtained. By relating effects at various levels to the many stakeholders involved in a network organisation, the framework does justice to its complexity. Moreover, it also gives a place to the dynamics of a network, typified by horizontal control. At the same time we conclude that the approach taken by Provan and Milward does not fully do justice to the contextual conditions within which the networking of local job centres takes shape. Two factors with respect to the institutional context appear to be important for the local job centres: the spatially differentiated and fragmented context of the Flemish local authorities and the context of multilevel steering and control of employment placement policy. 
By locating the 'principals' in the network at local level only, Provan and Milward incorrectly give the impression that networks are only controlled at local level. However, this is usually not the case for public service networks, which became embedded at supralocal level in the blossoming of the postwar welfare state. The importance of that level-with the breaking down of national barriers to the establishment of public services and the European steering of policy - continues to increase. Belgium offers in no way an exception for strong centrally organised public employment services. In the Belgian federal state this means the central level of the Flemish region. Furthermore, the social partners enjoy great credibility as managers of the Flemish public employment service (VDAB). Historically, corporatism was deeply rooted in the organisation of the social security system. The VDAB organisation can be characterised by a strongly centralised department which leaves little scope for the local labour market regions. The position of the local authorities in Flanders in the field of job brokerage (in a broad sense) is moreover limited due to the residual nature of the social assistance benefit system and the fragmented position of small and medium-sized municipalities. There is also another important explanatory factor behind the expansion drive of the Flemish public service: the desire to make the most of the Flemish competence and throw off the old RVA shackles. To some extent unintentionally, this also fuelled a monopolist attitude on the part of the VDAB towards other players in the market and even in the public sphere (Struyven, 2006).

One could ask in which direction the local integrated job centre services should evolve. Two factors seem important in this respect. First, there is the growing labour shortage on the Flemish labour market reinforced by a rapidly growing older workforce, more dynamic inflow and outflow in unemployment figures, and a diminishing inflow of school leavers. In this respect the Flemish government tends to expand the role of the local job centres to the working population in order to stimulate work-to-work transitions and facilitate the individual's career development. Second, the activation policy, possibly strengthened by a new devolution of competences to the regions (cf current state reform), urges for a tighter coupling of benefit and placement functions even at the local job centre. In that case a major redesigning will become inevitable. A combination of both scenarios is likely, and both will affect the position of workless people.

\section{References}

Bogason P, 2000 Public Policy and Local Governance: Institutions in Postmodern Society

(Edward Elgar, Cheltenham, Glos)

Clasen J, Ducan G, Eardley T, Evans M, Ughetto P, Van Oorschot W, Wright S, 2001, “Towards 'single gateways'? A cross-national review of the changing roles of employment offices in seven countries" Zeitschrift für Ausländisches und Internationales Arbeits- und Sozialrecht 15 43-63

Considine M, 2003, "Local partnerships: different histories, common challenges-a synthesis", in Managing Decentralisation: A New Role for Labour Market Policy (OECD, Paris) pp 253-272

Considine M, 2006, "Governments and communities in partnership: from theory to practice", keynote paper for government and communities in partnership conference, Centre for Public Policy, University of Melbourne, Melbourne

Derksen W, van Enckevort I, de Jong H, Schouten R, 1995 De Blik naar Buiten: Geïntegreerde Dienstverlening als Structuurprincipe Scientific Council for Government Policy, The Hague

Henman P, Fenger M (Eds), 2006 Administering Welfare Reform: International Transformations in Welfare Governance (Policy Press, Bristol)

Jensen M, Meckling W, 1976, "Theory of the firm: managerial behavior, agency costs and ownership structure" Journal of Financial Economics 3 305-360

Karagiannaki E, 2007, "Exploring the effects of integrated benefit systems and active labour market policies: evidence from Jobcentre Plus in the UK” Journal of Social Policy 36177 - 195

Kickert W, Klijn E, Koppenhan J, 1997 Managing Complex Networks: Strategies for the Public Sector (Sage, London) 
Koning P, 2007, "De effectiviteit van CWI medewerkers: aanvullende schattingen tot 2006", Centraal Planbureau, The Hague, http://www.cpb.nl/nl/pub/cpbreeksen/notitie/25mie2007/ notitie.pdf (in Dutch)

McQuaid R, Lindsay C, Dutton M, 2006, "Best practices in inter-agency co-operation on employability", Employment Research Institute, Napier University, Edinburgh

Mandell M, Keast R, Brown K, 2006, "Expanding the network evaluation territory: performance measures of different types of network", paper presented at the Tenth International Research Symposium on Public Management, 10-12 April, Glasgow Caledonian University

Pawson R, Tilley N, 1997 Realistic Evaluation (Sage, London)

Provan K, Milward H, 1995, "A preliminary theory of interorganizational network effectiveness: a comparative study of four community mental health systems" Administrative Science Quarterly $401-33$

Provan K, Milward H, 2001, "Do networks really work? A framework for evaluating public-sector organizational networks" Public Administration Review $61414-423$

Struyven L, 2006, "How market forces in public service delivery emerge and evolve: autonomous dynamics in the process of market competition on employment services in Australia, the Netherlands and Flanders", paper for ESPAnet Annual Conference, Bremen, 21 - 23 September, http://www.espanet2006.de/downloads/ESPAnet2006_paper_Struyven.pdf

Struyven L, Verhoest K, 2005, "The problem of agency at organisational and at street level: the case of the Flemish Public Employment Services", in Contractualism in Employment Services Eds E Sol, M Westerveld (Kluwer Law International, The Hague) pp 325-357

Swanborn P, 1999 Evalueren (Boom, Amsterdam) 
This article is an advance online publication. It will not change in content under normal circumstances but will be given full volume, issue, and page numbers in the final PDF version, which will be made available shortly before production of the printed version.

Conditions of use. This article may be downloaded from the E\&P website for personal research by members of subscribing organisations. This PDF may not be placed on any website (or other online distribution system) without permission of the publisher. 